Milica Tošić ${ }^{4}$

Škola za osnovno i srednje obrazovanje „Milan Petrović““ sa domom učenika, Novi Sad, Republika Srbija

Aleksandra Todorović ${ }^{5}$

Osnovna škola "Svetozar Marković Toza",

Novi Sad, Republika Srbija
UDC: 376:616.8-009.1-057.874

616.8-009.1-057.874:159.953.5

DOI: $10.19090 /$ ps.2018.2.127-142

Primljen: 30.10 .2018$.

Prihvaćen: 7.3.2019.

PREGLEDNI NAUČNI RAD

\title{
RAZVOJNI POREMEĆAJ KOORDINACIJE- IMPLIKACIJE NA ŠKOLSKU PRAKSU
}

\section{Rezime}

Razvojni poremećaj koordinacije (RPK) predstavlja neurološki poremećaj, odnosno poremećaj pokreta (procesa ideje, motornog planiranja i izvršenja pokreta). RPK utiče na svakodnevne veštine ali i na školska postignuća. Visoka prevalencija (5-8\%) govori u prilog tome da u svakom razredu ili vrtićkoj grupi možemo očekivati jedno dete/učenika za ovim problemom. Danas, za dijagnostikovanje ovog poremećaja koristimo DSM-V (Diagnostic and Statistical Manual of Mental Disorders, Fifth Edition) klasifikaciju (četiri kriterijuma). Prema ovom statističkom priručniku RPK se dijagnostikuje ako je izvođenje motoričkih veština ispod hronološkog uzrasta, ako ometa svakodnevne aktivnosti, ako je početak u razvojnom periodu $i$ ako se motorički deficit ne može objasniti nekim drugim oštećenjem (npr. cerebralnom paralizom). Etilogija RPK je multifaktorska. Najviše problema učenici sa RPK pokazuju na nastavi fizičkog vaspitanja, srpskog jezika i matematike. Teškoće sa kojima se susreću su mnogobrojne počev od problema pripreme za čas fizičkog vaspitanja, učešća u takmičarskim igrama, preko problema čitanja, pisanja i računanja. U osnovi ovih teškoća leži problem motoričkog učenja. Zbog svega, vrlo je važno koristiti odgovarajuće strategije za rad sa ovim učenicima. Pravovremenim tretmanom, primenom odgovarajućih metoda i strategija u radu može se uticati na dalji tok $i$ ishod ovog razvojnog poremećaja.

Ključne reči: razvojni poremećaj koordinacije, motorički poremećaji, škola, školska praksa, strategije za rad sa decom sa RPK.

\footnotetext{
${ }^{4}$ milica.tosic@smp.edu.rs
}

${ }^{5}$ todorovica.93@gmail.com 


\section{Uvod}

Razvojni poremećaj koordinacije (RPK) predstavlja oštećenje motoričke koordinacije koja utiče na svakodnevne životne aktivnosti i akademska postignuća, a koje nije posledica intelektualne ometenosti, pervazivnog razvojnog poremećaja, psihijatrijskog, neurološkog ili opšteg medicinskog stanja (Sugden, \& Wade, 2013).

Visoka prevalencija (5-8 \%) govori o tome da u svakom razredu i u svakoj vrtićkoj grupi možemo očekivati barem jedno dete sa RPK. Uprkos visokoj prevalenci, ovaj razvojni poremećaj je nedovoljno poznat našoj stručnoj javnosti, počev od zdravstvenih radnika, pa do pedagoško-psihološke službe i nastavnika u školi. I sami roditelji nisu informisani o osnovnim obeležjima ovog poremećaja, što otežava njegovu ranu identifikaciju i efikasan tretman.

Najveći broj učenika se identfikuje u školskom periodu zbog povećanja zahteva koji su postavljeni pred učenika. Teškoće su najuočljivije u nastavi fizičkog vaspitanja (zbog zasićenosti motoričkim aktvnostima), ali su vidljive i na drugim predmetima (srpski jezik i matematika). Ne postoji mnogo istraživanja koja se bave problemima RPK u našoj sredini, iako u svetu ova problematika pobuđuje sve veći istraživački interes (Magalhăes, Missiuna, \& Wong, 2006), pa se u skladu s tim i tema našeg rada odnosila upravo na implikacije RPK na školsku praksu.

\section{Definisanje razvojnog poremećaja koordinacije}

Razvojni poremećaj koordinacije (RPK) je neurološki poremećaj zasnovan na procesima koji su uključeni u planiranje i izvođenje pokreta, koji mogu da utiču na sticanje novih znanja i naučenih veština. Dakle, to je poremećaj pokreta, odnosno procesa ideje (formiranje ideje koristeći poznati pokret da bi se postigla planirana namera), motornog planiranja (planiranje akcije koje je potrebno za postizanje ideje), i izvršenja pokreta (sprovođenje planiranih pokreta). RPK utiče na svaku osobu na različite načine u različitim godinama i fazama razvoja, i u različitom stepenu. To je u suprotnosti, po tome što može da utiče na dete jednog dana, ali ne i sledećeg, i može da utiče na decu na različite načine u različitim uzrastima i razvojnim fazama (Krstić, 2008).

Prema DMS III-R Američkog psihijatrijskog udruženja, poremećaj u koordinaciji motorike prvi put je 1987. godine nazvan "Sindromom nespretnog deteta" (Magalhaes et al., 2006). Od tada su korišćeni brojni termini za opis dece sa razvojnim poremećajem koordinacije. Najčešće korišćen sinonim je dispraksija, zatim specifični razvojni poremećaj motornih funkcija, nespretnost, sindrom nespretnog deteta, poremećaj motornih veština, 
diskoordinacioni poremećaj, motorna dispraksija, perceptivno-motorna disfunkcija, senzornointegrativna disfunkcija, manja moždana disfunkcija i slično (Portwood, 1999).

Takva neujednačena terminologija otežavala je svakodnevni rad istraživača kao i proučavanje samog razvojnog problema. Nakon Međunarodne konferencije o dečjoj nespretnosti 1994. godine u Londonu (Ontario), počeo se koristiti termin "Razvojni poremećaj koordinacije (RPK)" (engl. developmental coordination disorder, DCD) kako bi se opisalo stanje kod dece sa lošom motornom koordinacijom (Magalhaes et al., 2006). Pregledne studije relevantnih naučnih članaka pokazuju da je ovaj termin u kasnijem periodu najzastupljeniji (Geuze, Jongmans, Schoemaker, \& Smits-Engelsman, 2001).

Razvojni poremećaj koordinacije je jedan od najčešćih poremećaja u detinjstvu i po nekim autorima prevalenca ide čak i do 19\% (Emond, Golding, Hunt, Jongmans, \& Lingam, 2009). Prema većini studija, RPK pogađa više dečake nego devojčice, a odnos varira od 2:1 do 5:1, u zavisnosti od ispitivane grupe (Gaines, Missiuna, \& Soucie, 2006).

\section{Dijagnostikovanje razvojnog poremećaja koordinacije}

Dijagnoza razvojnog poremećaja koordinacije ne treba da se postavlja deci mlađoj od 5 godina (Leeds Consensus Statement, 2006), prvenstveno zbog nestabilnosti samog razvoja dece uzrasta između 2. i 5. godine (Sugden, \& Wade, 2013). U većini slučajeva dijagnoza se postavlja u uzrastu od 6. do 12. godine života deteta (Barnhart, Davenport, Epps, \& Nordquist, 2003). Većina ove dece ne bude identifikovana, a među decom sa dijagnozom, oko $25 \%$ se identifikuje u predškolskom dobu, a preostalih $75 \%$ upravo u prvim godinama školovanja (Appleton, Appleton, \& Gibbs, 2007). Dijagnozu RPK kod dece obično potvrđuju pedijatri, ali roditelji i nastavnici igraju važnu ulogu u ranoj identifikaciji ovog razvojnog poremećaja. Učitelji mogu biti u prednosti u odnosu na druge stručnjake, jer posmatraju veći broj dece u raznovrsnim aktivnostima, od igre na odmoru, do pisanja, oblačenja i korišćenja različitog pribora (Cairney et al., 2008). Lekar pedijatar pregledom isključuje druge moguće bolesti i stanja koji bi mogli rezultovati motornom nespretnošću. Takođe, potrebno je da defektolog isključi poteškoće u učenju. Procenu je moguće izvršiti bez dijagnoze, ali dijagnoza se ne može postaviti bez procene.

Kriterijumi za postavljanje dijagnoze RPK su se vremenom menjali. Trenutni dijagnostički kriterijum je opisan u DSM-V (Diagnostic and Statistical Manual of Mental Disorders, Fifth Edition) na osnovu čega se postavlja i dijagnoza (American Psychiatric Association, 2013). Prema DSM-V kriterijumi dijagnostikovanja su svrstani u četiri kategorije: 
Prvi kriterijum: izvođenje koordinisanih motoričkih veština je ispod očekivanog za određeni hronološki uzrast i prilika za učenje veština; teškoće se manifestuju kao nespretnost (ispuštanje objekata i udaranje u objekte), usporenost i neadekvatnost izvođenja motoričkih veština (kao npr. hvatanje objekata, upotreba makaza, teškoće u pisanju, vožnji bicikla ili češće u sportskim aktivnostima).

Drugi kriterijum: dijagnoza RPK se postavlja samo ako ovo oštećenje značajno i trajno ometa svakodnevne aktivnosti očekivane za hronološki uzrast, školsko (akademsko) postignuće, predprofesionalne ili profesionalne aktivnosti i igru.

Treći kriterijum: početak simptoma je u ranom razvojnom periodu.

Četvrti kriterijum: motorički deficit ne može biti objašnjen intelektualnom ometenošću ili vizuelnim oštećenjem i nije povezan sa neurološkim stanjima koja utiču na motoriku (cerebralna paraliza, mišićna distrofija ili degenerativne bolesti) (American Psychiatric Association, 2013).

Iako se ovi kriterijumi primenjuju, teško ih je operacionalizovati. Jedan od glavnih problema u identifikaciji RPK jeste nepostojanje tzv. zlatnog standarda za procenu motorne koordinacije (Crawford, Dewey, Kaplan, \& Wilson, 2002). Preporuka je da se koriste normativni testovi opšte motorne kompetencije i 5. percentil kao granična vrednost (Geuze, Jongmans, Schoemaker, \& Smits-Engelsman, 2001). Najčešće korišćena baterija motornih testova je Movement assessment battery for children (MABC) (Henderson, \& Sugden, 1992) koja pokazuje i najbolja svojstva (Geuze et al., 2001).

\section{Etiologija razvojnog poremećaja koordinacije}

Etiologija razvojnog poremećaja koordinacije je još uvek nedovoljno poznata, deo autora RPK definiše kao idiopatsko stanje (Sutton-Hamilton, 2002). Različite teorije pokušavaju da objasne skrivene mehanizme razvojnog poremećaja koordinacije, a identifikovanje uzroka od značaja je za kliničku praksu, jer tretman može da se razlikuje u zavisnosti od etiologije (Hay et al., 2008). Etiologija razvojnog poremećaja koordinacije je po svemu sudeći multifaktorska, a najviše ispitivani faktori obuhvataju: oštećenje ili disfunkciju mozga, genetsku predispoziciju, deficit u obradi informacija i osiromašenu sredinu, tj. redukovane mogućnosti za sticanje motoričkih iskustava (Cermak, Gubby, \& Larkin, 2002).

Problemi u vezi sa prijemom i obradom informacija često se navode kao mogući uzrok slabe motorne koordinacije kod dece (Cermak et al., 2002). Ranije teorije, tzv. hijerahijske teorije ukazivale su na deficite u senzornoj integraciji, potom su usledile više kognitivistički 
orijentisane teorije usmerene na motornu kontrolu u funkciji rešavanja motornog problema, dok aktuelni pristupi počivaju na teoriji dinamičkih sistema (Hillier, 2007).

Za RPK su uobičajeni porodični klasteri; porodičnu istoriju nespretnosti pokazuje 21$30 \%$ slučajeva dece sa RPK (Cermak et al., 2002). U slučajevima komorbiditeta RPK i poremećaja pažnje sa hiperaktivnošču, polovina dece sa ovim stanjem ima brata/sestru ili roditelja sa sličnim poremećajem (Gillberg, 2003). Postoje dokazi o manjoj genetskoj uslovljenosti razvojnog poremećaja koordinacije u poređenju sa poremećajem pažnje sa hiperaktivnošću (Attention Deficit Hyperactivity Disorder, ADHD) (Hay et al., 2008).

\section{Problemi učenika sa razvojnim poremećaj koordinacije u školi}

RPK se najčešće detektuje na školskom uzrastu zato što tada poteškoće ovih učenika, zbog zahteva okoline, postaju najizraženije. Istraživanja pokazuju da ovaj poremećaj značajno utiče na akademska postignuća. Akademska postignuća nisu ugrožena samo zbog problema učenika u motoričkom domenu. Uvek treba imati na umu i koperzistirajuće probleme sa kojima se učenici suočavaju i tretirati ih podjednako kao i dominantne motoričke probleme (Emond, Harrowell, Hollen, \& Lingam, 2018).

U većini istraživanja se navodi da uspeh u školi učenika sa RPK ne pokazuje uvek i njihove stvarne sposobnosti. Naime, učenici koji imaju RPK najčešće imaju poteškoće sa savladavanjem osnovnih veština za učenje, čitanjem i pisanjem. Tako, oni neće uspeti da urade neki zadatak ne zato što ga ne shvataju ili zato što ne znaju da ga reše, nego zato što imaju probleme u drugim domenima koji im onemogućavaju fokusiranje na sam zadatak (Missiuna, Rivard, \& Pollock, 2004).

Veoma je važno da učitelji budu edukovani da prepoznaju učenika sa RPK. Škola je okruženje u kome sve detetove poteškoće mogu doći do izražaja. Ukoliko se one pravilno prepoznaju, moguć je i blagovremeni početak tretmana i strategija prilagođavanja u cilju bolje adaptacije na školsko okruženje i većih mogućnosti napredovanja (Ellinoudis, Gitsas, Kiparissis, \& Kourtesis, 2009). Međutim, podaci iz literature pokazuju da učitelji uglavnom nemaju znanja koja bi im pomogla u detekciji bilo kog razvojnog poremećaja. Ipak, oni su uglavnom voljni da idu na dodatne edukacije gde bi usavršili svoje znanje o prirodi razvojnih poteškoća, kao i načinima prepoznavanja učenika koji se suočavaju sa problemima u savladavanju školskih zadataka. Rezultati koje iznose Elinudis i saradnici (Ellinoudis et al., 2008) ukazuju da učitelji koji prođu edukaciju o razvojnim smetnjama bolje prepoznaju učenike sa ovim problemima. 
Iako je u poslednje vreme dosta pažnje posvećeno izučavanju razvojnih poteškoća u školskim okvirima, i dalje većina ovih učenika ostaje neprepoznata i okarakterisana kao lenja, nemarna, nezainteresovana ili čak bezobrazna. Iz tog razloga, u daljem tekstu su izdvojene najvažnije karakteristike učenika sa RPK koje se lako mogu uvideti u različitim školskim domenima. Obrađeni su problemi sa kojima se ovi učenici susreću u oblasti srpskog jezika, matematike i nastave fizičkog vaspitanja, jer su tu njihove teškoće zapažene kao najizraženije.

\section{Problemi učenika sa razvojnim poremećajem koordinacije u nastavi Srpskog jezika}

U oblasti srpskog jezika učenici sa RPK najčešće imaju probleme sa čitanjem i pisanjem. S obzirom da su čitanje i pisanje dva osnovna oruđa za učenje u višim razredima, neophodno je da deca njima ovladaju u nižim razredima. Problemi u čitanju i pisanju često onemogućavaju učenicima da usvajaju nova znanja i veštine u školskom okruženju (Chen, Cheng, Cherng, Shen, \& Tsai, 2011). Mekenzi i Vilson (McKanzie, \& Wilson, 1998) navode da u osnovi problema sa čitanjem i pisanjem kod učenika sa RPK leže njihove teškoće u vizuelnoj i kros-modalnoj percepciji. Slabije razvijena vizuelna percepcija učenicima otežava da percipiraju slova, reči i rečenice. Kros-modalna percepcija uključuje prevođenje informacije primljene preko jednog senzornog inputa u drugi modalitet (prilikom pisanja diktata auditivne informacije se prevode $u$ vizuelnu formu).

Pored problema vizuelne percepcije na učeničku veštinu čitanja i pisanja može uticati i problem sa memorijom. Učenici sa RPK često navode da im je teško da se prisete kako se određeno slovo izgovara (ne mogu se setiti foneme koja odgovara grafemi koju vide). Pažnja, koncentracija i sposobnost relokalizacije pogleda utiču na brzinu i egzaktnost čitanja. Prilikom pisanja učenici imaju poteškoće prizivanja odgovarajućeg slova (Chen et al., 2011). Izveštaji učitelja i nastavnika o uspešnosti učenika sa RPK u čitanju i pisanju uglavnom govore u prilog tome da su ovi učenici nesigurni, spori čitači i da im treba više vremena da prepišu ili zapišu ono što im se govori. Rezultati pokazuju da oni prave česte i duge pauze i da ne prate tekst dok drugi učenici čitaju. Ukoliko ih se prekine u čitanju, potrebno im je dosta vremena kako bi našli tačno mesto u tekstu gde su stali sa čitanjem. Neretko se dešava da supstituišu ili „gutaju“ slova, pa čak i cele reči, kako kada čitaju tako i kada pišu. Zapisi ovih učenika su izrazito neuredni, nečitki, neorgaizovani i sa dosta slovnih grešaka. Neurednosti doprinosi i često brisanje slova, koje je posledica pogrešnog zapisivanja. Neorganizovanost se kod učenika sa RPK ogleda u zanemarivanju margina, pisanju od sredine reda ili pisanju do sredine reda, neodvajanju reči, rečenica i pasusa (Chen et al., 2011; Livneh-Zirinski, \& Rosenblum, 2008). Zbog toga što prave česte pauze (60\% vremena predviđenog za pisanje oni 
provedu praveći pauze), zapišu mnogo manje nego što je očekivano. Najčešće se to dešava zato što ne mogu da se sete kako se piše naredno slovo i zato što njihova veština pisanja nije automatizovana, već svaki naredni pokret moraju posebno da isplaniraju (Barnett, Plumb, Prunty, \& Wilmut, 2014). Još jedan od problema vezanih za pisanje koji se može videti u školi je i neadekvatan pritisak olovke na papir (suviše slab ili suviše jak pritisak). Suviše slab pritisak rezultuje jedva vidljivim zapisom na papiru, a suviše jak pritisak cepanjem papira (Barnett, Plumb, Prunty, \& Wilmut, 2014).

\section{Problemi učenika sa razvojnim poremećajem koordinacije u nastavi Matematike}

Ukoliko se obrati pažnja na didaktičke principe, koji govore da dete prvo treba da manipuliše stvarnim objektima, potom da rešava polukonkretne zadatke sa brojevima, a tek onda i apstraktne zadatke, primetićemo da je motoričko učenje u osnovi matematičkog učenja. Takođe, motoričke veštine klasifikacije, serijacije i brojanja su neophodne za razvoj predmatematičkih veština, a potom i mentalne reprezentacije matematičkih koncepata. Mentalne reprezentacije vode razumevanju jednostavnih i složenih matematičkih operacija (Desoete, Pieters, Roeyers, Van Waelvelde, \& Vanderswalmen, 2012). Desoet i saradnici (Desoete et al., 2012), navode da učenici sa blažim oblikom RPK imaju isti nivo matematičkih znanja kao i učenici koji su hronološki godinu dana mlađi od njih. Učenici sa težim oblikom zaostaju za svojim vršnjacima u matematičkim znanjima čak dve godine.

Učitelji izveštavaju da učenici sa RPK pokazuju teškoće u rešavanju jednostavnih i složenih zadataka. Takođe, zapažaju da im teže ide oduzimanje nego sabiranje i da više problema imaju sa mentalnim računanjem nego sa poznavanjem numeričkog sistema. Desoet i saradnici (Desoete et al., 2012) beleže da ovakav obrazac problema pokazuju i učenici bez motoričkih smetnji. Istovremeno, Alovej i Arčibald (Alloway, \& Archibald, L, 2008), zapažaju da učenici sa RPK koji imaju slabije vizuospacijalne sposobnosti pokazuju više problema u oblasti numeričkih operacija (sabiranje, oduzimanje, deljenje, množenje, razlomci i algebra) i u oblasti matematičkog rezonovanja od učenika koji imaju bolje vizuospacijalne sposobnosti. Ovi autori sugerišu da se, pored motoričkog deficita, deficit u vizuelnoj radnoj memoriji smatra snažnim prediktorom dečjih matematičkih sposobnosti.

Smatra se da deficiti u aritmetici kod učenika sa RPK proizilaze iz niza problema na nižim instancama. Čak i ako se problem otkrije na višim nivoima matematičkog procesuiranja, srž problema je u osnovi matematičkog učenja. Tako će većina učenika koja ima probleme sa procesuiranjem nesimboličkih brojeva imati problem i sa procesuiranjem simboličkih brojeva, sa računanjem i rešavanjem kompleksnih matematičkih zadataka 
(Dehaene et al., 2015). Zadaci koji zahtevaju sekvencionsanje u svom rešavanju mogu predstavljati problem učenicima sa RPK s obzirom na njihove probleme u organizaciji. Pogrešno rešenje može biti rezultat nemogućnosti određivanja koji korak se radi u kom trenutku, nemogućnosti praćenja sleda zadatka ili sleda hijerarhije matematičkih operacija.

\section{Problemi učenika sa razvojnim poremećajem koordinacije u nastavi Fizičkog vaspitanja}

Glavne karakteristike razvojnog poremećaja koordinacije u motoričkom domenu su: slaba posturalna kontrola (umerena hipotonija ili hipertonija, slaba distalna kontrola, statička i dinamička ravnoteža), poteškoće u motoričkom učenju (učenju novih veština, planiranju pokreta, adaptaciji na promenu, automatizaciji) i slaba senzomotorna koordinacija (koordinacija udova, korišćenje povratne informacije, strateško planiranje i dr.) (Geuze, 2005). Najčešće se ovi problemi identifikuju upravo na nastavi fizičkog vaspitanja.

Učenici sa RPK imaju poteškoće sa samostalnim presvlačenjem za nastavu fizičkog vaspitanja, koje su posledica ograničene fine motorike (teškoće vezivanja pertli, zakopčavanja dugmadi). Neretko se problem javlja i u razlikovanju prednje i zadnje strane odevnih predmeta. Problemi sa posturom i ravnotežom uslovljavaju ih da sede prlikom pripreme za nastavu fizičkog vaspitanja.

Za učenje novih motoričkih veština potrebno im je mnogo više truda, ali često taj trud ne rezultuje uspehom. Ponovljeni neuspesi dovode do frustracije. Problemi sa koordinacijom i pažnjom dodatno otežavaju učenje novih motoričkih veština. Prilikom davanja naloga, zapaža se da postoji dugotrajna latenca između postavljenog naloga i izvršenja motoričke aktivnosti. Zbog postojanja latence, učenici deluju lenjo ili neposlušno, a oni sami nisu tog svesni. Tako oni smatraju da se od njih traži preterana brzina i spretnost. Za druge misle da previše žure, da su preki i nervozni (Bailey, 2003; Cairney et al., 2007; Lavay, 2005; Missiuna, 2003; Missiuna et al., 2006; Skinner \& Piek, 2001).

Primećeno je da na času fizičkog vaspitanja deca koja su nespretna češće demonstriraju ponašanje koje nije u vezi sa zadatkom i manje uživaju u nastavi fizičkog vaspitanja. Zbog svoje nespretnosti, često se sapliću o predmete i sudaraju sa drugom decom, što ih čini izloženim potencijalnom zadirkivanju i podsmehu (Cairney et al., 2007). I oni sami ocenjuju svoje fizičke kompetencije kao niske. Zato se neretko javljaju dodatni problemi: loši odnosi sa vršnjacima, nisko samopoštovanje, internalizujući problemi (anksioznost i loše raspoloženje, depresija). Učenici sa RPK su češće izloženi vršnjačkom nasilju i oni su, da ne bi bili žrtve maltreiranja i ponižavanja, skloni povlačenju u sebe i izbegavanju socijalnih kontakata (Missiuna et al., 2006). 
Nastavnici fizičkog vaspitanja mogu značajno da doprinesu prepoznavanju i proceni RPK jer su edukovani da posmatraju i procenjuju kretanje, vode proces motornog učenja i prate učenike u raznovrsnim motoričkim situacijama. Za nastavnike fizičkog vaspitanja važan kriterijum da li dete ima RPK ili se samo razvija sporije od prosečne dece jeste brzina napredovanja uz vežbanje. Ako se dete relativno brzo popravlja uz vežbanje, verovatno je da nema RPK (Đorđić, 2010). Kod deca koja su nespretna evidentno je postojanje spirale neuspeha: zbog nespretnosti, deca izbegavaju učešće u fizičkoj aktivnosti. Manje učešće u fizičkoj aktivnosti povlači za sobom nižu kondiciju, doprinosi gojaznosti i daje manje prilika za uvežbavanje motornih veština, rezultirajući još slabijim veštinama. Formiranje ciklusa inaktivnosti može izložiti decu koja su nespretna većem riziku za kardiovaskularne bolesti u odraslom dobu (Cairney et al., 2007).

\section{Terapijske intervencije i strategije za pomoć u školi učenicima sa razvojnim poremećajem koordinacije}

Svi tretmani koji se koriste u radu sa učenicima sa RPK se mogu podeliti u četiri grupe: tretmani orijentisani ka procesu (pristup „od dna naviše“), tretmani orijentisani ka zadatku (pristup ,sa vrha nadole“), klasični tretmani radne terapije i biomedicinske intervencije. Ono što je bitno je da svi tretmani pokazaju uspešnost, a kao najuspešniji se izdvaja tretman orijentisan ka zadatku (Blank et al., 2012). Tretmani orijentisani ka zadatku obezbeđuju instrukcije specifičnih motoričkih veština, kao što je zakopčavanje jakne, hodanje stepenicama bez padanja ili udaranja. Zadaci na koje će se orijentisati intervencija su definisani od strane samog učenika, roditelja i nastavnika. Smatra se da je ova vrsta tretmana najefikasnija zato što omogućava učeniku da se skoncentriše na sam zadatak, umesto na njegove komponente i da se uvežbavanjem jednog motoričkog zadatka uvežbavaju i jednostavniji motorički obrasci (Blank et al., 2012).

$\mathrm{U}$ istraživanjima koja se bave objašnjavanjem i ispitivanjem različitih vrsta tretmana, neizostavan je naglasak na radu sa učenicima u školi. Većina autora naglašava važnost uključivanja u sve nastavne, vannastavne aktivnosti u školi kao i u aktivnosti igre. Oni ohrabruju učitelje i pedagoško-psihološku službu da pomogne učeniku da pronađe svoj kutak u učionici gde će se osetiti sigurnim za učenje, druženje, igru i fizičke aktivnosti. Naglašava se da jedino uključenjem deteta u sve životne tokove i školsku sredinu možemo očekivati uspeh bilo kog tretmana (Lange, 2018).

Ponekad edukatori pokušavaju da smanje nastavno opterećenje za ovu decu, što zapravo rezultira smanjenim akademskim očekivanjima. Učenicima sa RPK obično nije 
potreban modifikovan program, već su dovoljna određena prilagođavanja. Neke od strategija prilagođavanja će biti prikazane u nastavku teksta.

\section{Strategije prilagođavanja u okviru nastave Fizičkog vaspitanja}

- Omogućiti učeniku više vremena da se pripremi za čas fizičkog vaspitanja (oblačenje);

- Obezbediti kutak u uglu svlačionice za presvlačenje ili pomoć para;

- Davati jasna i koncizna uputstva, razložiti motoričku veštinu na manje celine i dati više vremena za uvežbavanje;

- Obratiti pažnju da učenik stoji blizu nastavnika;

- Obezbediti dovoljan prostor za igru;

- Prilagoditi nastavni materijal (niži koš, širi gol);

- Organizovati rad u manjim grupama ili rad u paru prlikom uvežbavanja;

- Prilikom učenja novih veština, organizovati individualni rad sa učenikom ili rad u paru;

- Koristiti kalendare aktivnosti;

- Usmerenost dodatne pažnje ka učenicima sa RPK (Ball, 2002).

\section{Strategije prilagođavanja u okviru nastave Srpskog jezika}

- Na vrh olovke se može staviti guma koja će sprečiti prste da klize prilikom pisanja;

- Preporučiti roditeljima kupovinu trouglaste olovke;

- Nacrtati krug na olovci koji ukazuje gde treba da se stave prsti;

- Obojiti ključna mesta na olovci i učenikovim prstima, kako bi znao gde koji prst treba da stavi;

- Pre pisanja, podstaći učenika da vežba svoj stisak tako što će stavljati gumice na vrat tegle, gužvati bilo kakav krut materijal ili igrati se sa plastelinom;

- Zalepiti papir za sto kako se ne bi pomerao prilikom pisanja ili koristiti plastične ograde koje će zadržavati papir;

- Uvek obezbediti dodatno vreme za zapisivanje;

- Dozvoliti učeniku upotrebu diktafona ili tableta/kompjutera;

- Postepeno povećavati brzinu pisanja i obim pisanog materijala kako bi se sprečilo umaranje, frustracija i izbegavanje aktivnosti pisanja; 
- Eliminisati vizuelne distraktore;

- Obezbediti zakrivljenu podlogu;

- Koristiti plastične graničnike (okvire za čitanje kako bi se izolovali delovi teksta);

- Preporučiti upotrebu markera za beleženje važnih delova teksta;

- Vežbati vizuelnu percepciju (puzle, igre klasifikovanje, uočavanje skrivenog objekta, igre traženja reči, igre ciljanja, domine);

- Vežbe okulomotorike (kompjuterske igrice, praćenje objekata po učionici) (Ball, 2002).

\section{Strategije prilagođavanja u okviru nastave Matematike}

- Pripremiti učeniku zadatke na odštampanim radnim listićima (poželjno je da svaki zadatak bude na posebnom listiću);

- Ukoliko zadaci uključuju aktivnosti fine motorike, obezbediti dodatno vreme za završavanje zadataka;

- Korišćenje računara za zapisivanje zadataka;

- Obezbeđivanje dodatnog konkretnog materijala za razumevanje zadataka;

- Omogućiti vršnjačku podršku ( $\operatorname{rad} u$ paru);

- Uvek se uveriti da je učenik tačno prepisao zadatak (Ball, 2002).

\section{Zaključak}

RPK je najčešći poremećaj koji se javlja u razvojnom periodu. Teškoće sa kojima se susreću ove osobe nisu ograničene samo na aktivnosti svakodnevnog života već i na aktivnosti u školskom okruženju. Učitelji i nastavnici imaju priliku da posmatraju decu u različitim situacijama, da ih porede sa vršnjacima, pa su njihova opservacija i mišljenje reperi za dijagnostikovanje ovog poremećaja.

Vrlo je važno pravovremeno identifikovati RPK kako bi se preveniralo javljanje dodatnih posledica primarnog motoričkog oštećenja. Nastavu treba prilagoditi učeniku izborom odgovarajućih metoda i strategija u radu. Prilagođavanja se mogu primeniti u svim nastavnim predmetima, ali najviše prilagođavanja je prisutno u nastavi Fizičkog vaspitanja, Srpskog jezika i Matematike. Korišćenjem strategija, učenik će bolje organizovati svoj rad i izvršavati školske zadatke. Nastavnik će upotrebom strategija pružiti pravovremenu i 
adekvatnu podršku učeniku sa RPK. Naglasak treba da bude na zalaganju i učestvovanju, umesto na takmičenju i perfekcionizmu. Zbog svega navedenog treba aktivno raditi na edukaciji školskog osoblja o ovom problem, ali i načinima pomoći učenicima sa RPK.

\title{
Milica Tošić
}

School for Primary and Secondary Education "Milan Petrović"

Novi Sad, Serbia

\section{Aleksandra Todorović}

Elementary School "Svetozar Marković Toza"

Novi Sad, Serbia

\section{THE DEVELOPMENTAL COORDINATION DISORDER - IMPLICATIONS FOR SCHOOL PRACTICE}

\begin{abstract}
The Developmental Coordination Disorder (DCD) is a neurological disorder, or a movement disorder (the idea process, motor planning and execution of movement). DCD affects everyday skills and school achievements. High prevalence $(5-8 \%)$ points out that in every class or kindergarten group one child/pupil can be expected with this problem. Today, the DSM-V classification (four criteria) is used for establishing diagnosis of this disorder. According to this statistical manual, the DCD is diagnosed if the performance of motor skills is below the chronological age, hinders everyday activities, the beginning is in the developmental period and the motor deficit cannot be explained by some other damage (e.g. cerebral paralysis). The DCD's etiology is multifactorial. Pupils with DCD encounter most problems in physical education, language education (Serbian language) and mathematics. They come across numerous difficulties starting from the problem of preparation for class, participation in competitive games, through reading, writing and calculation. The basis of these difficulties lies in the problem of motor learning. Therefore, it is important to use appropriate strategies in work with these pupils. Timely treatment and application of appropriate methods and strategies can influence the further course and outcome of this developmental disorder.
\end{abstract}

Key words: Developmental Coordination Disorder (DCD), motor disorder, school, school practice, strategies in work with children with DCD 


\section{Literatura}

1. Alloway, T. P., \& Archibald, L. (2008). Working memory and learning in children with developmental coordination disorder and specific language impairment. Journal of Learning Disabilities, 41(3), 251-262.

2. American Psychiatric Association. (2013). DSM-V: Diagnostic and Statistical Manual of Mental Disorders. $5^{\text {th }}$ ed. Washington, DC: American Psychiatric Association.

3. Appleton, J., Appleton, R., \& Gibbs, J. (2007). Dyspraxia or developmental coordination disorder: unravelling the enigma. Archives of Disease in Childhood, 92, 534-9.

4. Bailey, R. (2003). Teaching physical education: A handbook for primary and secondary school Teachers. London: Kogan Page Limited.

5. Ball, M. (2002). Developmental coordination disorder: Hints and tips for the activities of daily living. London: Jessica Kingsley Publishers.

6. Barnett, A., Plumb, M., Prunty, M., \& Wilmut, K. (2014). An examination of writing pauses in the handwriting of children with Developmental Coordination Disorder. Research in Developmental Disabilities, 35, 2894-2905.

7. Barnhart R. C., Davenport M. J., Epps S. B., \& Nordquist V. M. (2003). Developmental coordination disorder. Physical Therapy, 83(8), 722-31.

8. Blank, R., Mosterd-Van Der Meijs, R., Polatajko, H., Smits-Engelsman, B., Van Der Kaay, A., Vlugt-Van Den Brand, E., \& Wilson, P. (2013). Efficacy of interventions to improve motor performance in children with developmental coordination disorder: a combined systematic review and meta-analysis. Developmental Medicine \& Child Neurology, 55, 229-237.

9. Cairney, J., Faught, B. E., Flouris, A., Hay, J., Mandigo, J., \& Wade, T. (2007). Developmental coordination disorder and reported enjoyment of physical education in children. European Physical Education Review, 13 (1), 81-98.

10. Cairney, J., Faught, B. E., Hay, J., Missiuna, C., Spironello, C. A., \& Veldhuizen, S. (2008). Screening for motor coordination challenges in children using teacher ratings of physical ability and activity. Human Movement Science, 27, 177-189.

11. Cermak, S. A., Gubbay, S. S., \& Larkin, D. What is developmental coordination disorder? In Cermak, S. A., \& Larkin, D. (Eds), Developmental coordination disorder (pp. 2-22). Albany, Delmar Thompson Learning. 
12. Crawford, S. G., Dewey, D., Kaplan, B. J., \& Wilson, B. N. (2002). Developmental coordination disorder: associated problems in attention, learning, and psychosocial adjustment. Human Movement Science, 21, 905-918.

13. Chen, J-Y., Cheng, H-C., Cherng, R-J., Shen, M-L., Tsai, C-L. (2011). Reading and writing performances of children 7-8 years of age with developmental coordination disorder in Taiwan. Research in Developmental Disabilities, 12, 2589-2594.

14. Dehaene, S., Dehaene-Lambertz, G., Gomez, A., Huron, C., Jobert, A., \& Piaza, M. (2015). Mathematical difficulties in developmental coordination disorder: Symbolic and nonsymbolic number processing. Research in Developmental Disabilities, 43-44, 167- 168.

15. Desoete, A., Pieters, S., Roeyers, H. Van Waelvelde, H., \& Vanderswalmen, R. (2012). Mathematical problems in children with developmental coordination disorder. Research $\quad$ in Developmental Disabilities, 33, 1128-1135.

16. Đorđić, V. (2010). Nespretno dete u nastavi fizičkog vaspitanja. Nastava $i$ vaspitanje, $3,425-36$.

17. Emond, A., Golding, J., Hunt, L., Jongmans, M., \& Lingam, R. (2009). Prevalence of Developmental Coordination Disorder Using The DSM-IV at 7 Years of Age: A UK Population Based Study. Pediatrics, 123 (4), 693-700.

18. Emond, A., Harrowell, I., Hollen, L., \& Lingham, R. (2018). The impact of developmental coordination disorder on educational achievement in secondary school. Research in Developmental Disabilities, 72, 13-22.

19. Ellinoudis, T., Gitsas, K., Kiparissis, M., \& Kourtessis, T. (2009). Ability to detect movement difficulties in children aged 7-12 years by physical education teachers using the assessment package Movement Assessment Battery for Children. Physical Education \& Sports, 29(3), 288-306.

20. Ellinoudis, T., Kioumourtzoglou, E., Kiparissis, M., Kourtessis, T., Maheridou, M., Tsigilis, N. (2008). The influence of a short intervention program on early childhood and physical education teacher ability to identify children with developmental coordination disorders. Journal of Early Childhood Teacher Education, 2(4), 276-286.

21. Gaines, R., Missiuna, C., \& Soucie, H. (2006). Why every office needs a tennis ball: a new approach to assessing the clumsy child. Canadian Medical Association Journal, 175(5), 471-473. 
22. Geuze, R. H. (2005). Postural control i children with developmetnal coordination disorder. Neural Plasticity, 12, 183-96.

23. Geuze, R. H., Jongmans, M. J., Schoemaker, M. M., \& Smits-Engelsman. (2001). Clinical and research diagnostic criteria for developmental coordination disorder: a review and discussion. Human Movement Science, 20, 7-47.

24. Gillberg, C. (2003). Deficits in attention, motor control, and perception: a brief review. Archives of Disease in Childhood, 88, 904-10.

25. Hay, D. A., Levy, F., Martin, N. C., Pearsall-Jones, J. G., Piek, J. P., \& Rigoli, D. (2008). A monozygotic twin design to investigate etiological factors for DCD and ADHD. Journal of Pediatric Neurology, 6(3), 209-19.

26. Henderson, S. E., \& Sugden, D. A. (1992). Movement assessment battery for children. London: Psychological Corporation.

27. Hillier, S. (2007). Intervention for children with developmental coordination disorder: a systematic review. The Internet Journal of Allied Health Sciences and Practice. Retrived October 2018 from http://ijahsp.nova.edu

28. Krstić, N. (2008). Razvojna neuropsihologija. Beograd: Fakultet za specijalnu edukaciju i rehabilitaciju.

29. Lange, S. (2018). ADHD and Comorbid developmental Coordinationd Disorder: Implications and Recommendations for School Psychologists. Contemporary School Psychology, 22, 30-39.

30. Lavay B. W. (2005). Specific learning disabilities, In J. P. Winnick (Ed.), Adapted physical education and sport (pp. 189-204). Champaign, IL: Human Kinetics.

31. Leeds Consensus Statement: Developmental coordination disorder as a specific learning difficulty. (2006). Leeds: Economic and Social Research Council.

32. Livneh-Zirinski, M., \& Rosenblum, S. (2008). Handwriting process and product characteristics of children diagnosed with developmental coordination disorder. Human Movement Science, 27(2), 200-214.

33. Magalhăes, L. C., Missiuna, C., \& Wong, S. (2006). Terminology used in research reports of developmental coordination disorder. Developmental Medical \& Child Neurology, $48 . \quad 937-941$.

34. McKanzie, B. E., \& Wilson, P. H. (1998). Information processing deficits associated with developmental coordination disorder: A meta-analysis of research findings. Journal of Child Psychology and Psychiatry, and Allied Disciplines, 39, 829-840. 
35. McLean, J., Missiuna, C., Gaines, R., \& Soucie, H. (2006). Parental questions about developmental coordination disorder: A synopsis of current evidence. Paediatrics and Child Health, 11(8), 507-512.

36. Missiuna, C. (2003). Children with developmental coordination disorder: at home and in the Classroom. Hamilton, ON: CanChild, Centre for Childhood Disability Research.

37. Missiuna, C, Gaines, R, Soucie, H, McLean, J. (2006): Parental questions about developmental coordination disorder: A synopsis of current evidence. Paediatrics and Child Health, $\quad$ 11(8), 507-512.

38. Missiuna, C., Pollock, N., \& Rivard, L. (2004). They're bright but can't write: Developmental coordination disorder in school aged children. Canadian Journal of Occupational Therapy, 73, 7-17.

39. Pavlović, D. (2011). Neuropsihologija sa osnovama bihevioralne neurologije. Beograd: Kaligraf.

40. Piek, J. P., \& Skinner, R. A. (2001). Psychosocial implications of poor motor coordination in children and adolescents. Human Movement Science, 20(1-2), 73-94.

41. Portwood M. (1999). Developmental Dyspraxia; Indetification and Intervention; A Manualfor parents and Professionals. $2^{\text {nd }}$ Edition. London: David Fulton Publishers.

42. Sugden D., \& Wade, M. (2013). Typical and Atipical Motor Development. London: Mac Keith Press.

43. Sutton-Hamilton S. (2002). Evaluation of clumsiness in children. American Family Physician, 66(8), 1435-40. 